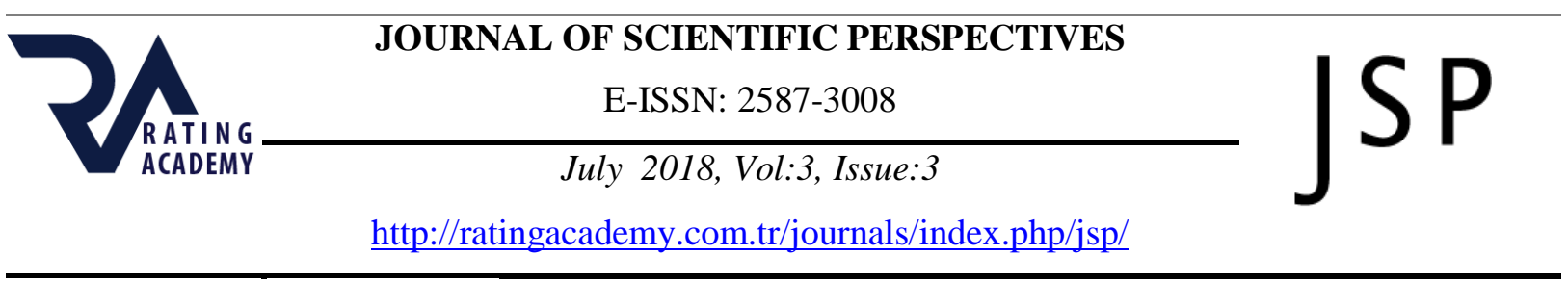

\title{
THE CONCEPT OF CARRYING CAPACITY IN TERMS OF SUSTAINABLE USE POLICIES: A CASE STUDY OF BAYRAMIÇ AYAZMAPINARI NATURAL PARK (ÇANAKKALE, TURKEY)
}

\author{
Dr. Çiğdem KAPTAN AYHAN* \\ Çanakkale Onsekiz Mart University, Faculty of Architecture and Design, Department of Landscape \\ Architecture, Çanakkale, Turkey \\ E-mail: cigdemayhan@yahoo.com
}

Neşe KARAKAYA, Nezahat KIRIT, ERMAN ÖZDEMIR, Kübra YANMAZ

Graduate Student, Division of Landscape Architecture, Graduate School of Natural and Applied

Sciences, ,Çanakkale, Turkey

\begin{tabular}{|c|c|}
\hline ARTICLE INFO & ABSTRACT \\
\hline $\begin{array}{l}\text { Article History: } \\
\text { Received: 02 July } 2018 \\
\text { Accepted: } 12 \text { July } 2018\end{array}$ & \multirow{3}{*}{$\begin{array}{l}\text { The idea underlying the understanding of sustainability is that mankind should } \\
\text { live in such a way that will not exceed the carrying capacity of the environment } \\
\text { in order to support it. That is, the sustainable management of natural resources } \\
\text { is the way to attain sustainable development. On the other hand, ecological } \\
\text { sustainability can be achieved only through conservation-based scientific } \\
\text { approaches. If the problems to be caused by the uncontrolled use of resources } \\
\text { are predicted in advance and if planning is made to this end, the sustainable use } \\
\text { of protected areas will be possible. The concept of "carrying capacity" and the } \\
\text { planning studies carried out within the framework of this concept are also } \\
\text { essential to hand protected areas down to the future. Within the framework of this } \\
\text { study, it was intended to determine the carrying capacity of Bayramiç } \\
\text { Ayazmapinart Natural Park, which was taken under conservation with the } \\
\text { "Natural Park" status in 2011 and which plays an important role in the } \\
\text { economic development of the locality. "The Method of Estimating the Carrying } \\
\text { Capacity in Protected Areas", recommended by the IUCN, was employed in the } \\
\text { research, which was carried out to ensure the sustainable use of the study area } \\
\text { with important natural and cultural landscape assets. As a result of the method, } \\
\text { it was established that Bayramiç Ayazmapinarl Natural Park had some intensity } \\
\text { of use above its carrying capacity. It was concluded that the intensive tourism } \\
\text { activities creating a rather negative situation in terms of the sustainability of } \\
\text { resources should be re-planned on the basis of conservation \& use. Proposals of } \\
\text { conservation policies were made in order to hand the existing natural and } \\
\text { cultural landscape assets down to future generations. Furthermore, the } \\
\text { incomplete or wrong uses in the area were highlighted and various suggestions } \\
\text { were made to this end in the research. }\end{array}$} \\
\hline $\begin{array}{l}\text { Keywords: } \text { sustainability, } \\
\text { tourism carrying capacity, } \\
\text { natural park, Bayramiç. }\end{array}$ & \\
\hline & \\
\hline
\end{tabular}

\section{INTRODUCTION}

Although the idea of conservation of featured areas dates back to centuries earlier, the evaluation of conservation decisions on a legal basis commenced more recently. It might be stated that the first systematic approach to this matter started with the declaration of Yosemite National Park in the U.S.A. in 1872. Following this, many countries declared protected areas 
on various scales. In this process, many environmental organizations were founded and various studies were presented due to the extensive framework of the concept of "conservation". The International Union for Conservation of Nature (IUCN), the largest of these organizations, was founded in 1948. With its 16,000 voluntary-specialized employees in total, it prepares guides in the international sense with regard to the definition and categorization of protected areas (URL 1). Within the framework of these guides, the IUCN defines a protected area as "a clearly defined geographical space, recognized, dedicated and managed, through legal or other effective means, to achieve the long-term conservation of nature with associated ecosystem services and cultural values" (URL 2).

In addition to this system by the IUCN, the categories of "Biosphere Reserve Sites" and "World Heritage Sites", defined by the United Nations Educational, Scientific and Cultural Organization (UNESCO), are available, and in addition to all these conservation classes, there are also many studies on different scales such as the Ramsar Convention, Natura 2000, PAN Parks, and the Determination of Biogenetic Reserves.

The process of categorization of protected areas in Turkey commenced with Law No. 2873 on National Parks, dated 09/08/1983. The aim of the law is to organize the fundamentals of selecting and determining the national parks, natural parks, natural monuments, and nature conservation areas with assets at national and international levels in our country as well as of protecting, developing, and managing them without any degradation of their features and characters. In this law Natural Park is defined as "the pieces of nature which have the characteristics of vegetation and wildlife and which are favorable for the people to rest and be entertained in the scenic integrity" (URL 3).

The common goal of all these conservation studies, performed at both national and international levels, is to provide that the resource assets of local, regional or global importance in these areas can be handed down to future generations.

The developed transportation and communication possibilities, the changing understanding of tourism (e.g. nature-based tourism activities) and the business investments rapidly increasing to this end have turned many protected areas into important tourism destinations. The uncontrolled increase in tourism activities in some areas in this process was effective in taking conservation decisions.

Uithol (2000) states that when tourism is planned and monitored carefully, it may become a significant instrument for the sustainable development of protected areas and their surroundings (Güneş, 2008). Especially given the scarcity of the income earned from the existing agricultural activities and the labor exerted, the overwhelming majority of the local people welcome the arrival of more tourists. The demand for these areas has also brought about investment activities on various scales. Hence, the anthropogenic effect has been more intensive in protected areas and their close vicinity. Nevertheless, the use of resources in such a way that is distant from conservation-based approaches and that allows obtaining maximum income in the short term leads to irreversible damage. In addition, although tourism initially satisfies the local people in terms of economic income, the incoming visitors cause various problems in the original and traditional life at the locality, which causes the people to have a negative attitude towards tourism.

At this point, the concept of sustainability has gained great importance for protected areas. According to Tekeli (2001), sustainability is a moral principle which originated within the environmental movement, which is quite widely accepted, and whose content is continually being intended to be re-determined in the political process (Inceday1, 2004). According to Kalem (2001) and Sethi (1999), the idea underlying the understanding of 
sustainability is that mankind should live in such a way that will not exceed the carrying capacity of the environment in order to support it. That is, the sustainable management of natural resources is the way to attain sustainable development. According to this understanding,

*the maintaining of ecological processes and the providing of continuity,

*preservation of biodiversity,

*the ensuring of equality among and within present and future generations and

*integration of social, environmental, and economic approaches constitute the fundamental principles of sustainable development (Güneş, 2008).

As Edwards (2005) indicated, the paradigm of sustainability was extensively presented in the report by the World Commission on Environment and Development in 1987 (Laven et al., 2015). In the same report (Our Common Future - the Brundtland Report), meeting the present social, environmental, and economic needs without sacrificing the ability of future generations to meet their similar needs (Moldan et al., 2012). According to Richardson (1995), sustainable development is a concept which addresses ecological equilibrium and economic growth together and which both provides the efficient use of natural resources and attaches importance to environmental quality. The attainment of sustainable development in a country will take place through the attainment of ecological sustainability, economic sustainability, and social sustainability (Gürlük, 2001). On the other hand, ecological sustainability can be provided only through conservation-based scientific approaches. If the problems to be caused by the uncontrolled use of resources are predicted in advance and if planning is made to this end, the sustainable use of protected areas will be possible. The concept of "carrying capacity" and the planning studies carried out within the framework of this concept are also essential to hand protected areas down to the future.

\section{THE CONCEPT OF CARRYING CAPACITY}

The first areas of application for the concept of carrying capacity are engineering and architecture. According to Çavuş, (2002), in the studies in these fields, the concept of carrying capacity was utilized as an instrument for planning so as to determine the capacity of physical structures (Soylu 2013). According to Sumner (1936), the first suggestion to apply the concept of carrying capacity to parks and similar areas was made in the 1930s. A National Park Report which made proposals of policies on parks in the California Mountains sought an answer to a question of what size of use there should be without any destruction of the basic features in natural areas (Manning, 2007). Moreover, in the report, it was recommended to confine the recreational use of natural areas to their carrying capacity. In a study on the recreational use of forests by Wagar in the following years, it was emphasized that the carrying capacity was crucial in all recreational activities in forests, particularly in intensively used areas. The first scientific application of the concept of carrying capacity in parks and similar areas was the studies carried out in the early 1960s by Wagar (1960) and Lucas (1964) (Manning, 2007). According to Fennel (2002), Lucas examined visitors' perceptions of wildlife in an area where the canoe sport was performed in his study in 1964 and suggested that the carrying capacity concerned environmental elements (Tokmak, 2008).

Since its first use, the concept of carrying capacity has been addressed under different conditions and in various disciplines by different circles, and many definitions have appeared. Even though the definitions have generally been similar, they have acquired different meanings according to the relevant discipline and their spheres of interest have expanded (Gül and Akten, 2005). 
According to the World Tourism Organization (WTO) (1981), the Carrying Capacity is defined as the maximum number of people that may visit a tourism area at the same time, without any destruction of the physical, economic, and sociocultural environments and without any undesirable decrease in visitors' satisfaction levels (UNEP-PAP, 2009). In addition, again the WTO also stated that the carrying capacity was fundamental to environmental conservation and sustainable development (Avc1, 2007). Carey (1993) stated that the carrying capacity was initially developed regarding wildlife management and that it was based on the fact that an organism could only live under certain conditions. The number of organisms in an environment is determined by the accessibility to favorable conditions for life (McCool and Lime 2001). According to Wearing and Neil (1999), the concept of carrying capacity is generally used to express the threshold at which a system can absorb the changes (Liu, 2003). While the carrying capacity significantly affects the sustainability of the potential of an area for tourism, there are also some factors which affect the carrying capacity (Table 1) (Holden, 2000).

Table 1. The factors affecting the carrying capacity in those areas where tourism activities are experienced (Holden, 2000).

\section{Factors affecting the carrying capacity}

$\checkmark$ Resistance of the landscape to development and change

$\checkmark$ Existing development of, and infrastructural \& superstructural possibilities for, tourism

$\checkmark$ Number of visitors

$\checkmark$ Type of tourists and their behavioral traits

$\checkmark$ Environmental education levels of the local people and tourists

$\checkmark$ The level of dependence of an area on tourism in economic terms

$\checkmark$ Levels of unemployment and poverty

$\checkmark$ Attitudes of the local people towards the environment and their opinions about the damage to the environment for a short-term gain

$\checkmark$ The perspectives of local cultures and societies on extrinsic impacts and different lifestyles

$\checkmark$ The organization level of destination management

It is possible to multiply the definitions of the carrying capacity. Although these definitions are quite similar to each other within a general framework, each type of carrying capacity has a distinct threshold value and different contents in terms of the development of tourism, as Liu (2003) also states. While Shelby and Heberlein (1984) related the carrying capacity to recreation and classified it as ecological, physical, social, and superstructural capacities, Pigram and Jenkins (1999) categorized the carrying capacity as physical, social, ecological, and economic capacities. On the other hand, O'Reilly (1986) grouped the carrying 
capacity as economic, psychological, environmental, and social carrying capacities (Holden, 2000).

When different classifications in various studies are considered, it is seen that many researchers agreed on the categories of ecological (environmental in some sources), economic, social, psychological, and physical carrying capacities.

It might be stated that the ecological carrying capacity has the greatest share in terms of the sustainability of protected natural areas. Many different researchers made various definitions on the subject. The common ground in the definitions of the ecological carrying capacity is the occurrence of no irreversible degradation in any element of the ecosystem. The ecological carrying capacity is of great importance to manage tourism activities and recreational use and to provide sustainability in natural areas.

It is suggested that the ecological carrying capacity refers to the limit to the anthropogenic activities which will cause undesirable changes in the environment (Avc1, 2007). Considering this, Walson stated that the ecological carrying capacity was concerned with at what level of use the whole ecosystem from plants and animals to soil, water, air, and beach erosion would be affected at the level of certain uses as well as with what the cost of this use would be (Çavuş, 2004 as cited in Avc1, 2007).

By making a reference to Pigram (1983), Papageorgiou and Brotherton (1999) mentioned the ecological carrying capacity as the maximum level of recreational use sustained in terms of activities and numbers before the occurrence of any unacceptable or non-renewable falls in ecological values in a region or an ecosystem, whereas Buckley (1999) evaluated the ecological carrying capacity on the basis of the number of tourists which would not lead to any irreversible ecological changes.

Tourism activities substantially influence the economic level of the local people. When considered from this perspective, the economic carrying capacity is also a significant factor in providing sustainability. According to Çavuş (2002), when the concept of carrying capacity is evaluated in the economic sense, it might be stated that it is concerned with the economic activities in touristic regions and based on the approach to the sustaining of touristic activities without any negative changes in the quality and quantity of these activities (Tokmak, 2008). The economic carrying capacity is concerned with the level of use of an area or a facility with a certain financial yield (Papageorgiou and Brotherton, 1999) as well as with the balance between the benefits of tourism to the region and its cost (Avc1, 2007). Lim (1998) lists the factors affecting the economic carrying capacity as follows: investment, volume of tourists, cost of the holiday, level of economic benefits provided, level of enjoyment suited to the residents and others.

The social carrying capacity is a concept which is evaluated on the basis of users/visitors in those areas where there is intensive recreational use. The individuals performing recreational activities in any area may come from different sections of the society. Hence, they have a wide variety of demands and opinions about the features of an area. Moreover, the traditional lifestyles and habits of the local people may be positively/negatively affected by tourism movements and intensive use by visitors. Shelby and Heberlein (1984) evaluated the social carrying capacity particularly in terms of visitors and put forward some parameters to determine the social carrying capacity:

*Encounters with other parties per hour, day etc.;

* Number of encounters with groups of a particular size and type;

*Percent of nights camped away from others;

*Percent of attraction sites where people are out of sound and sight of others; and 
*Number of people encountered at each attraction site.

Some of the above-mentioned parameters may vary by person. The social carrying capacity depends largely on personal perceptions. As Tokmak (2008) also states, starting from what point there will be a decline in the quality of experiences by tourists may display uncertainty. Even if it is accepted that under normal conditions, all other conditions (e.g. the environmental quality of the region, level of hospitality, overnight stay, catering, and entertainment possibilities) remain unchanged in a touristic region, a tourist may decide not to come to the region by thinking that the experience he/she has had in that region is enough and just so as to make a change.

Saveriades (2000) defines the social carrying capacity as the acceptable maximum level of use in an area without creating any dissatisfaction among visitors or any negative impact on the local people. Furthermore, he suggests that visitors' levels of satisfaction before they begin to seek a different destination and the levels of tolerance of the local people for the presence of tourists are two important components of the social carrying capacity.

In addition, it is rather difficult to know which of the impacts of tourism the local people will find unacceptable in the social sense and at what level. If studies to reveal these impacts in advance are carried out, it might be possible to go on using the land without exceeding the social carrying capacity values. Saveriades (2000) also states that the interaction among visitors, an area, and the local people living in an area gives rise to some social impacts and that these impacts are essential in the process of determining the deficiencies in capacity and adds that this point should be noted at the stage of planning.

Included in the concept of carrying capacity, the psychological carrying capacity is concerned with visitors' perception and levels of satisfaction. Thus, it is also used as the perceptual carrying capacity in some sources. Additionally, since perceptions by individuals play a significant role in this concept, the concepts of social carrying capacity and psychological (perceptual) carrying capacity may from time to time be used interchangeably as well. For instance, in their study, Lopez-Bonilla and Lopez-Bonilla (2008) considered them under the same heading as "social (psychological) carrying capacity". According to Tokmak (2008), the perceptual carrying capacity is closely related to tourists' satisfaction, while tourists' satisfaction is closely related to their expectations and purposes of coming to the touristic destination. Liu (2003) also addressed the psychological carrying capacity on the basis of visitors and related it to the perception and satisfaction by different tourists in different types of destinations and holidays.

The physical carrying capacity scrutinizes the issue particularly depending on the number of visitors and spatial adequacy. While Liu (2003) states that this concept is the maximum number of people that an area can hold, he expresses that the minimum quantity of area that a person may need is taken as the basis when making a numerical evaluation.

The physical carrying capacity not only means the maximum number of people who will use an area but also can be evaluated as the maximum equipment (e.g. a boat in a waterside recreational area) likely to be used in an area. This concept both may be a design concept and serves to create limits concerning security (the maximum number of users in any playfield). Moreover, the physical carrying capacity also provides indirect control on the number of users in any area (Pigram and Jenkins, 2006). Washburne (1982) states that many different elements (e.g. accessibility of the camping place at a campsite, situation and vegetation of the land, and the numbers of convenient campsites and of tents which can be used) might affect the physical carrying capacity in natural areas. Lim (1998) lists the factors affecting the physical carrying capacity of an area as follows: Area size, accessible space, 
visual impact, climate, aesthetics, accommodation quality, availability of facilities, transportation, number of people that can be accommodated and others.

The tourism mobility in Bayramiç Ayazmapınarı Natural Park (BANP), an important protected area in the region with its natural resource assets, should be taken under control with a conservation-based approach. In this study, the area was scrutinized in many aspects including the situation of the physical conditions of the area in terms of recreational activities. The natural park was assessed within the framework of the concept of carrying capacity, and various predictions were made with respect to the future of the area. Furthermore, various suggestions were made for the existing problems of use, and design solutions were presented.

\section{MATERIALS AND METHOD}

BANP constitutes the main material of the study. In addition, various publications on the subject of the research, the previous studies on the study area, the maps, information, and documents procured from the institutions, the on-site observations and examinations and the photographs taken make up the rest of the study material.

BANP is at a distance of $91 \mathrm{~km}$ from Çanakkale and $23 \mathrm{~km}$ from the district of Bayramiç and remains within the borders of the Evciler Village (Figure 1). The area is located in the massif of Mt Kaz and at an altitude of 490 meters. Located between 39 $44^{\prime} 51.1^{\prime \prime}$ -

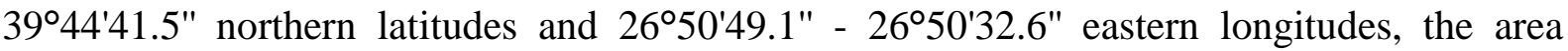
covers a forest habitat with a size of 5.85 ha. The area was taken under conservation with the Natural Park status in 2011.

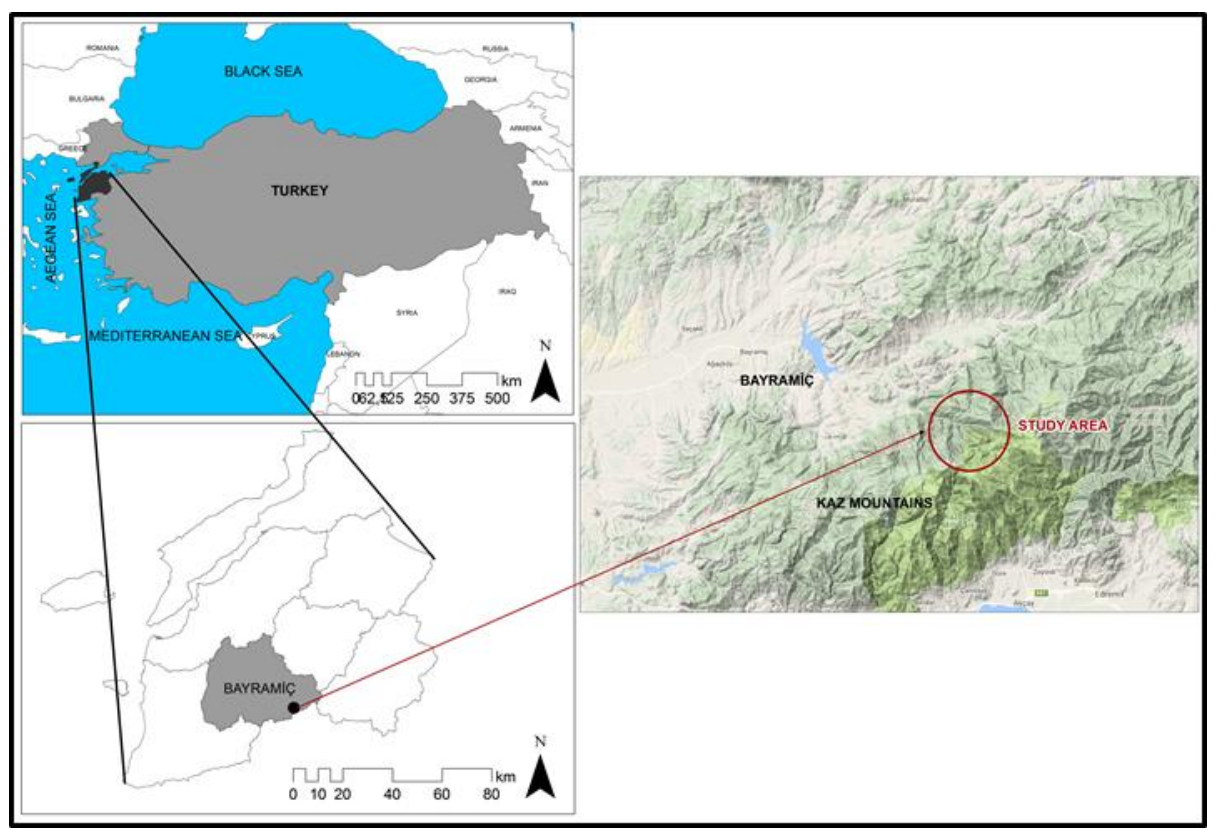

Figure 1. The geographical location of the study area (Database:1: ESRI maps, 2: Regional Directorate of Forestry, 3. www.atlas.gov.tr)

Pinus nigra stands constitute the dominant vegetation. Some vegetation which resembles that in the Black Sea Region is present along the Çınarcık and Ayazma Brooks two important water bodies located in the area. Species Castanea sp., Carpinus sp., Quercus sp., Platanus sp., Tilia sp., Fagus sp. and Corylus sp. are encountered in these sections. The area is within the Marmara sub-climate type of the Mediterranean climate type. Accordingly, it has lower summer temperatures, quite cold winters, normal snowfall, more frequent freeze, 
and a higher rate of cloudiness in comparison with the actual Mediterranean climate. This is a significant factor in recreationally preferring the study area in hot summer months. The study area has visually rich scenic examples together with its rich vegetation besides the brook passing through it and the resulting waterfall (Figure 2). Additionally, ecological tourism activities particularly like trekking in the forest are also among the activities frequently encountered in the area thanks to the richness of the biodiversity.

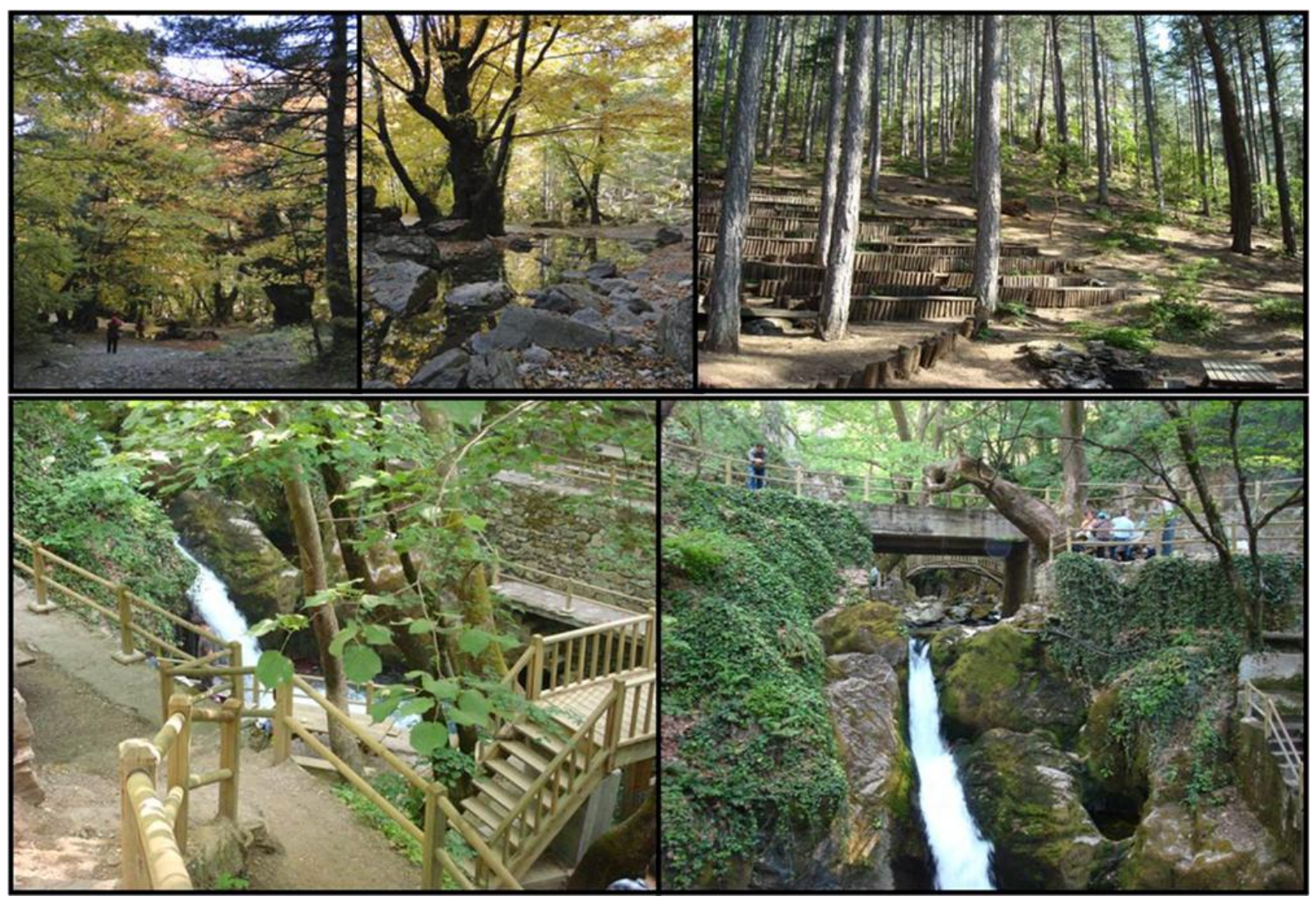

Figure 2. Waterfall and various images from the study area (Original, 2017).

The study area also has significant potential in cultural terms. As Koç (2008) also indicates, Mt Kaz and the Evciler Basin, where BANP is also located, constitute the mythological center for the Trojan Region and the source of all its riches and have a settlement past of over 6,000 years. The mythological sources mention that the first beauty contest on earth was held in Ayazma.

"The Method of Estimating the Carrying Capacity in Protected Areas", suggested by the IUCN and included in the study by Ceballos-Lascuráin (URL 4), was employed in the research. According to the method, three recreational carrying capacity levels are determined by using various parameters limiting visits in a formulation, namely "Physical Carrying Capacity", "Real Carrying Capacity", and "Effective Carrying Capacity". The formulae and explanations for these three carrying capacities are provided in Table 2.

The Physical Carrying Capacity (PCC) is the maximum number of people that can physically fit into a defined space at a specific time. The PCC is the multiplication of an area of $1 \mathrm{~m}^{2}$ or a 1-meter-long trail per visitor by the total area which is open to visitors' use and the number of visits which may physically be paid within the working hours of the park per day. 
The Real Carrying Capacity (RCC) is the maximum number of visits allowed in an area, and it is obtained by mathematically subtracting the correction factors obtained from specific negative features of the area from the PCC. These correction factors are obtained from biophysical, environmental, ecological, social, and managerial variables. According to the formula, the correction factors must be calculated first in order to find the RCC. The correction factors occur as a result of calculating the relationship between the limiting value of the factors which prevent or limit visiting and its total value with the method of interpolation. After all correction factors which are valid for the area have been calculated, they are mathematically subtracted from the previously calculated PCC. The correction factors expressed as percent values are put in their respective places in the formula.

The Effective Carrying Capacity (ECC) is the maximum number of visitors that an area can bear according to its existing management capacity. According to the formula, the ECC is the multiplication of the previously calculated RCC by the management capacity (MC). The MC is the sum of the conditions required in order for the management of a protected area to conduct its duties and objectives. It is not very easy to quantify the MC owing to the presence of a large number of variables such as legislation, infrastructure, superstructure and equipment, staff in number and quality, funds, and motivation. The ECC never turns out to be greater than the RCC.

Table 2. Formulation of the Carrying Capacity (URL 4)

\begin{tabular}{|c|c|c|}
\hline Definitions & Explanatic & \\
\hline \multirow{7}{*}{$\mathrm{PCC}=\mathrm{AxV} / \mathrm{a} \times \mathrm{Rf}$} & PCC & Physical Carrying Capacity \\
\hline & A & Area (The existing area or trail for visitors' \\
\hline & $\mathrm{V} / \mathrm{a}$ & \\
\hline & & Visitor / area (Area or trail length per visitor) \\
\hline & $\mathrm{Rf}$ & $\begin{array}{c}\text { (in the area: } 1 \text { visitor } / m^{2} \text {; on the trail: } 1 \\
\text { visitor } / m \text { ) }\end{array}$ \\
\hline & $R f$ & $\begin{array}{l}\text { Rotation factor (Number of visits per day) "The } \\
\text { Rotation Factor" is the daily visits which are } \\
\text { allowable in terms of the working hours in an } \\
\text { area }\end{array}$ \\
\hline & & $\begin{array}{l}\text { The period during which the area is open daily } \\
\text { / The average duration of a visit }\end{array}$ \\
\hline \multirow{2}{*}{$\begin{array}{l}\mathrm{RCC}=\mathrm{PCC}-\mathrm{Cf}_{1}-\mathrm{Cf}_{2}-\ldots \ldots \cdot- \\
\mathrm{Cf}_{\mathrm{n}}\end{array}$} & \multirow{2}{*}{$\begin{array}{l}\mathrm{Cf}_{1}, \quad \mathrm{Cf}_{2}, \\
\mathrm{Cf}_{\mathrm{n}}\end{array}$} & Correction factors calculated for each variable \\
\hline & & Correction Factor $(\%)$ \\
\hline \multirow{2}{*}{$\begin{array}{l}\mathrm{Cf}=\mathrm{Vl} / \mathrm{Vt} \mathrm{X} 100 \\
=P C C \times(100-C f 1 / 100) x \\
(100-C f 2 / 100) \times \ldots . . \times(100- \\
C f n / 100)\end{array}$} & $\mathrm{Cf}$ & Limiting Value of the Variable \\
\hline & $\begin{array}{l}\mathrm{Vl} \\
\mathrm{Vt}\end{array}$ & Total Value of the Variable \\
\hline \multirow{3}{*}{$\mathrm{ECC}=\mathrm{RCC} \times \mathrm{MC}$} & ECC & Effective Carrying Capacity \\
\hline & $\mathrm{RCC}$ & Real Carrying Capacity \\
\hline & $\mathrm{MC}$ & Management Capacity \\
\hline
\end{tabular}




\section{RESULTS}

The physical, real and effective carrying capacities of BANP were calculated within the framework of the method described in the Method section.

\section{The Physical Carrying Capacity (PCC)}

In order for visitors to tour the area in BANP, they must follow the route which consists of bridges and trails. The PCC-related features of the area:

$\checkmark$ The linear length covered by a person on the trails: $1 \mathrm{~m}$

$\checkmark$ Total length of the trails: $550 \mathrm{~m}$

$\checkmark$ Duration of visit (on average): 5 hours

$\checkmark$ Period during which the area is open to visits: 10 hours

$\checkmark$ Maximum size of a group of visitors: 45 people

$\checkmark$ Minimum spacing among the groups: $45 \mathrm{~m}$

As the recommended minimum spacing among the groups is $45 \mathrm{~m}, 6$ groups will fit into the 550-meter-long trails. Accordingly:

$[(6$ groups $\times 45 \mathrm{~m})+(5$ spaces $\times 45 \mathrm{~m})=495 \mathrm{~m}]$. If these 6 groups visit the area at the same time, a total trail length of $270 \mathrm{~m}$ will be required. The rotation factor must be calculated to determine the PCC.

Rf: Period during which the area is open daily / Average duration of a visit

Rf: 10 hours / 5 hours Rf: 2 visits / day

When the numerical values obtained are put in their respective places in the formula:

PCC: $270 \mathrm{~m} \times 1$ visitor/m x 2 visits/day

PCC: 540 visits/day

\section{The Real Carrying Capacity (RCC)}

The climate factor is an important factor in terms of the recreational activities performed in the study area. Therefore, the 34-year (1980-2014) meteorological data about Çanakkale were obtained from the Directorate General for Meteorology of the Ministry of Forestry and Water Affairs, and the numerical values obtained from these data were used to calculate the correction factors. The RCC-related features of the area are as follows:

$\checkmark$ Number of days when the temperature is greater than or equal to $25^{\circ} \mathrm{C}$ (annual mean): 121.9 days

$\checkmark$ Daily hours of sunshine: 7.2 hours

$\checkmark$ Period during which the sunshine is the most intensive: 4 hours (11 a.m.-3 p.m.)

$\checkmark$ Number of days when precipitation is $\geq 0.1 \mathrm{~mm}$ (annual mean): 83.9 days

$\checkmark$ Average duration of rainfall: 2 hours

$\checkmark$ Mean number of stormy days (wind speed: $17.2 \mathrm{~m} / \mathrm{sec}$ ): 44.2 days

$\checkmark$ Period during which the wind is effective: 2 hours

Some correction factors which limit visiting must be calculated to compute the RCC. Correction factors occur as a result of calculating the relationship between the limiting value 
of the factors which prevent or limit visiting and the total value with the method of interpolation. The correction factors were determined as temperature, precipitation, and storm in BANP. The operations concerning the correction factors are presented in Table 3.

Table 3. Limiting Correction Factors

\section{CORRECTION FACTORS}

\section{Correction Factor for Temperature}

$\mathrm{Cf}_{\mathrm{t}}: \quad \mathrm{Vl} / \mathrm{V}_{\mathrm{t}} \times 100$

$\mathrm{V}_{1}: \quad 121.9$ disturbing hot days $\mathrm{x} 4$ disturbing hot hours $=487.6$

$\mathrm{V}_{\mathrm{t}}$ : $\quad 121.9$ disturbing hot days $\mathrm{x} 7.2$ sunny hours $=877.6$

$\mathrm{Cf}_{\mathrm{t}}: \quad 487.6 / 877.6 \times 100=55.5(\mathbf{5 5 . 5 \%})$ limitation

\section{Correction Factor for Precipitation}

$\mathrm{Cf}_{\mathrm{p}}: \quad \mathrm{Vl} / \mathrm{V}_{\mathrm{t}} \times 100$

V1 : $\quad 83.9$ rainy days x 2 rainy hours $=167.8$ hours/year

$\mathrm{V}_{\mathrm{t}}$ : $\quad 5$ visiting hours $\mathrm{x} 365$ days $=1,825$ hours $/$ year

$\mathrm{Cf}_{\mathrm{p}}: \quad 167.8 / 1,825 \times 100=9(\mathbf{9 \%})$ limitation

\section{Correction Factor for Storm}

$\mathrm{Cf}_{\mathrm{s}}: \quad \mathrm{V}_{\mathrm{l}} / \mathrm{V}_{\mathrm{t}} \times 100$

$\mathrm{V}_{1}: \quad 44.2$ stormy days $\mathrm{x} 2$ stormy hours $=88.4$

$\mathrm{V}_{\mathrm{t}}$ : 5 visiting hours $\mathrm{x} 365$ days $=1,825$ hours $/$ year

$\mathrm{Cf}_{\mathrm{s}}: \quad 88.4 / 1,825 \times 100=4(4 \%)$ limitation

When the percent values found to calculate the RCC of the area are put in their respective places in the formula, it turns out that:

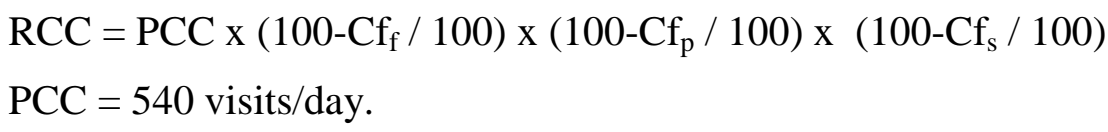

So,

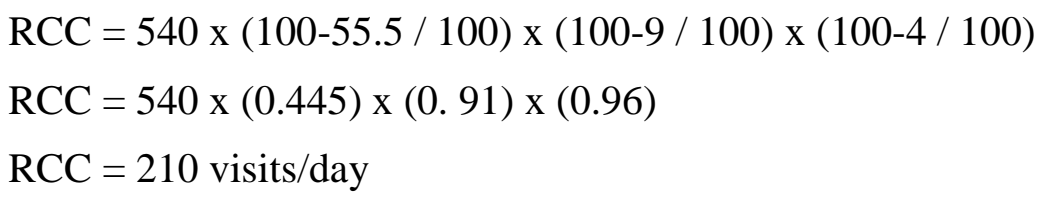

\section{The Effective Carrying Capacity (ECC)}

According to the information obtained from the Provincial Directorate for Nature Conservation and National Parks, the predicted number of staff members for BANP is 5 and the number of staff members available is 2 . According to this information, the Management Capacity of the area can be calculated as follows:

$\mathrm{MC}=$ Number of Staff Members Available / Minimum Number of Staff Members Required x 100

$$
\begin{aligned}
& \mathrm{MC}=2 / 5 \times 100=40(40 \%) \\
& \mathrm{ECC}=\mathrm{RCC} \times \mathrm{MC}
\end{aligned}
$$




$$
\begin{aligned}
& \mathrm{ECC}=210 \times 0.4 \\
& \mathrm{ECC}=84 \text { visitors/day }
\end{aligned}
$$

As a result of the method of study, the ECC of BANP was found as 84 visits/day. The number of visitors that the area might accept per year was calculated as 30,660 (84 visitors/day x 365 days $=30,660$ visitors/year).

\section{DISCUSSION AND CONCLUSION}

According to the data obtained from Çanakkale Provincial Directorate for Nature Conservation and National Parks of the Ministry of Forestry and Water Affairs, the number of visitors to BANP was 55,764 people in 2014; furthermore, again according to the data by the same institution, the number of visitors in a period of 5 months (June, July, August, September, and October) was 30,375 people in 2015. At this point, it is seen that the carrying capacity of the area was exceeded about twofold in 2014. On the other hand, the capacity limit was reached only in the period of 5 months in 2015. It is inevitable that the natural landscape features of the area (e.g. vegetation, animal stock, and water resources) will be negatively affected by this intensive use by visitors.

Diversification and acceleration of communication possibilities are quite essential for the development of tourism. However, this leads to a more intensive tourism movement in natural areas in particular. Although BANP is an area which is known and preferred by the people in the region, it is becoming an important destination point of Çanakkale nationwide upon the developing technology. This reveals that a conservation-based management plan should be drawn up rapidly for the sustainability of the resource assets of the area.

BANP also has various problems concerning the design of the area, along with the exceeding of its carrying capacity. In the examinations carried out in the area so as to reveal these problems, it was seen that the incoming vehicles mostly parked on the roadsides due to the lack of places in which an adequate number of parking lots could be constructed. Therefore, necessary arrangements (e.g. parking lot lines) should be made on the roadsides in terms of vehicle and pedestrian security. Furthermore, garbage elements, WC units, arbors and picnic tables were discovered to be inadequate. It was found out that children's playgrounds should be renewed with the tools and equipment suitable for the mental and physical development of children. For the security of individuals, regular maintenance and repair should be carried out on the wooden bridges that the visitors use when touring the area. A security point should be built at the entrance of the area. No arrangement for handicapped individuals is available within BANP. Regarding this matter, constructional solutions with accurate standards should be formed for handicapped individuals at all points where the topographical features of the area allow.

Fire (particularly due to the use of barbecues) is an important element of danger in the area. Barbecuing should be prevented outside the allowed areas, and necessary arrangements for control at the time of fire should be made at critical points. The local people in particular visit the study area largely for picnicking. By carrying out various activities for the local people, the area should be considered for other purposes, but not just with the concept of a "picnic area". Various activities which will enhance the awareness of individuals to recognize and protect the natural and cultural features of BANP should be performed. Moreover, introductory panels describing the natural and cultural features of the area and prepared individually for adults and children should be available. Regular sales units should be created in order for the local people to sell their own crops to visitors.

BANP is an area which should be protected with care in ecological terms particularly due to its rich vegetation. However, as Kuss and Graefe (1985) also state, one of the most 
serious problems encountered in recreational resource areas by decision-makers about the area and by those who manage the area is the coincidence of the studies for the conservation of the natural ecosystem and the recreational uses. The study area is also confronted with similar problems. However, as Göktuğ et al. (2013) state by making a reference to Akten (2009), the goal adopted in the use of protected areas is to conserve natural and cultural assets and hand them down to future generations.

The natural and cultural landscape features of BANP, whose recreational carrying capacity is intended to be determined within the framework of this research, should be detected in detail with a large-scale study; it should be assessed in terms of different types of carrying capacity as well; and plan decisions for the future should be taken in light of the information to be obtained. As known, the contribution of protected natural areas to the tourism sector and hence to the development process is quite significant. Given this, the consciousness of the local people of the importance of this area and its close vicinity - which they also make use of in economic terms - as well as of the need to conserve them should be enhanced through various training activities. Adoption of the principle of participation when making plan decisions about protected areas will also enable the local people to have a more constructive attitude. Otherwise, the practices exceeding the self-renewability power of those natural features which are damaged by various uses in BANP and all similar protected natural areas will give rise to irreparable consequences.

There are many protected areas under different categories in Turkey, which houses very different natural landscape features not only on the local scale but also nationwide. These areas, in which tourism activities of various sizes and types are also ongoing, are under the responsibility of different institutions such as the Ministry of Forestry and Water Affairs, the Ministry of Environment and Urbanization, and the Ministry of Culture and Tourism. This causes differences in approaches in the planning performed. In addition, carrying capacity approaches and methods are not included in the plans on various scales drawn up by the relevant units of these ministries. Nevertheless, it should be acknowledged that the providing of sustainability in those protected natural areas particularly where there are intensive tourism activities depends on determining the carrying capacity of the area primarily in ecological terms and in every aspect.

In conclusion, protected natural areas are sensitive points for the whole world ecosystem. They are also striking and demanded destinations in terms of tourism because of the features they involve. Significant progress on sustainability will be achieved through the joint planning and policies that all relevant fields of science and institutions will draw up by considering the conservation-use balance in the context of handing these areas down to future generations. 
KAPTAN et al. / The Concept of Carrying Capacity in Terms of Sustainable Use Policies: A Case Study of Bayramiç Ayazmapınarı Natural Park (Çanakkale, Turkey)

\section{REFERENCES}

AVCI, N. 2007, Turizmde Taşıma Kapasitesinin Önemi, Ege Akademik Bakış, 7 (2), 493509.

BUCKLEY, R. 1999, An Ecological Perspective on Carrying Capacity, Annals of Tourism Research, 26 (3), 705-708.

GÖKTUĞ, TH., Y D. NALAN, DEMIR M, BULUT Y. 2013, Taşıma Kapasitesi Kuramının Milli Parklarda Oluşum-Gelişim ve Modellenme Süreci, Atatürk Üniversitesi Ziraat Fakültesi Dergisi, 44 (2), 195-206.

GÜL, A, AKTEN, M. 2005, Korunan Doğal Alanlarda Rekreasyonel Taşıma Kapasitesi ve Kavramsal Yaklaşımlar, Korunan Doğal Alanlar Sempozyumu, 8-10 Eylül 2005, Isparta.

GÜNEŞ, G. 2008, Korunan Alanlar ve Çevresi İçin Sürdürülebilir Turizm Gelişim Stratejisi, III. Balıkesir Ulusal Turizm Kongresi, 17-19 Nisan 2008, Balıkesir.

GÜRLÜK, S. 2001, Dünyada ve Türkiye'de Kırsal Kalkınma Politikaları ve Sürdürülebilir Kalkınma, Uludă̆ Üniversitesi İktisat Fakültesi Dergisi, 19 (4).

HOLDEN, A. 2000, Environment and Tourism, Routledge Taylor and Francis Group, New York.

İNCEDAYI, D. 2004, Çevresel Duyarlılık Bağlamında Davranış Biçimi Olarak Sürdürülebilirlik, Mimarlık, 318.

KOÇ, T. 2008, Bayramiç Barajı Havzası (Evciler, Çanakkale) Potansiyeli ve Olası Sorunlar, Bayramiç Değerleri Sempozyumu,- Çanakkale Il Değerleri Sempozyumu, 25-31 Ağustos 2008, Bayramiç, Çanakkale.

KUSS FR. and GRAEFE AR. 1985, Effects of Recreation Trampling on Natural Area Vegetation, Journal of Leisure Research, 17 (83), 165-183.

LAVEN, DN., WALL-REINIUS, S, FREDMAN, P. 2015, New Challenges for Managing Sustainable Tourism in Protected Areas: An Exploratory Study of the European Landscape Convention in Sweden, Society and Natural Resources, 28 (10), 11261143.

LIM, CL. 1998, Carrying Capacity Assessment of Pulau Payar Marine Park, Malaysia (FAO, Bay of Bengal Programme).

LIU, Z. 2003, Sustainable Tourism Development:A Critique, Journal of Sustainable Tourism, 11(6), 459-475.

LÓPEZ-BONILLA, JM and LÓPEZ-BONILLA, LM. 2008, Measuring Social Carrying Capacity: An Exploratory Study, Tourismos: An International Multidisciplinary Journal of Tourism 3 (1), 116-134.

MANNING, RE. 2007, Parks and Carrying Capacity Commons Without Tragedy, Island Press, Washington.

MCCOOL, SF. and LIME, DW. 2001, Tourism Carrying Capacity: Tempting Fantasy or Useful Reality?, Journal of Sustainable Tourism, 9 (5), 372-388.

MOLDAN, B., JANOUŠKOVÁ, S., HÁK, T. 2012, How to Understand and Measure Environmental Sustainability: Indicators and Targets, Ecological Indicators 17, 4-13. 
KAPTAN et al. / The Concept of Carrying Capacity in Terms of Sustainable Use Policies: A Case Study of Bayramiç Ayazmapınarı Natural Park (Çanakkale, Turkey)

PAPAGEORGIOU, K and BROTHERTON, I. 1999, A Management Planning Framework Based on Ecological, Perceptual and Economic Carrying Capacity: The Case Study of Vikos-Aoos National Park, Greece, Journal of Environmental Management, 56 (4), 271-284.

PIGRAM, JJ. and JENKINS, J M. 2006, Outdoor Recreation Management, Routledge Taylor and Francis Group.

SAVERIADES, A. 2000, Establishing the Social Tourism Carrying Capacity for the Tourist Resorts of the East Coast of the Republic of Cyprus, Tourism Management, 21 (2), 147-156.

SHELBY, B and HEBERLEIN, THOMAS A., 1984, A Conceptual Framework For Carrying Capacity Determination, Leisure Sciences, 6 (4), 433- 451.

SOYLU, Y, 2013, Turistik Destinasyonlarda Taşıma Kapasitesi: Gelibolu Yarımadası Tarihi Milli Parkı Örneği, Thesis (MSc), Çanakkale Onsekiz Mart University.

TOKMAK, C. 2008, Sürdürülebilir Turizm Açısından Taşıma Kapasitesi, Topkapı Sarayı Örneği, Thesis (Ph.D), Gazi University.

UNEP (United Nations Environment Programme) - PAP (Priority Actions Programme), 2009, Sustainable Coastal Tourism /An Integrated Planning and Management Approach.

WASHBURNE, RF. 1982, Wilderness Recreational Carrying Capacity: Are Numbers Necessary?, Journal of Forestry, 80 (11), 726-728.

URL 1: http://www.iucn.org/secretariat/about Data Accessed: 19.07.2016

URL 2: https://www.iucn.org/theme/protected-areas/about Data Accessed: 19.07.2016

URL 3:

http://www.resmigazete.gov.tr/main.aspx?home=http://www.resmigazete.gov.tr/arsiv/18132 .pdf\&main=http://www.resmigazete.gov.tr/arsiv/18132.pdf Data Accessed: 19.07.2016

URL 4: https://portals.iucn.org/library/efiles/html/tourism/cover.html Ceballos-Lascuráin H., 1996, Tourism, Ecotourism and Protected Areas, IV World Congress on National Parks and Protected Areas, IUCN The Word Conservation Union 1996, ISBN 2-83170124-4 Data Accessed: 10.06.2016 
KAPTAN et al. / The Concept of Carrying Capacity in Terms of Sustainable Use Policies: A Case Study of Bayramiç Ayazmapınarı Natural Park (Çanakkale, Turkey) 